https://doi.org/10.31874/2520-6702-2021-11-1-192-200

UDC: 378

\title{
Aleksandrova Nataliya
}

\author{
Enhancing leadership qualities for conflict management in intercultural business \\ environments \\ (as part of professional and foreign language preparation of future economists of \\ international economic relations)
}

\begin{abstract}
The goal of this writing is to advocate the significance of educating and enhancing leadership qualities and skills for successful conflict management situations. By analyzing the current trends in doing business nationally and globally, understanding approaches to manage conflicts in a cross-cultural business environment we have identified professional requirements for graduates seeking beneficial and successful careers in international business, economic relationships and management. Analyzing relevant articles the author points out that today's business environment is notably sustainability-driven and aimed at maintaining the conditions that allow it to flourish in cross-cultural teams over time. Thus, organizations' leaders and managers are and will be aimed at building enduring business institutions. The author underlines the importance of acquiring cultural awareness, basic knowledge of conflict management and cultivating leadership qualities in the process of foreign language preparation at university. The novelty of our research lies in the fact that we have undertaken an attempt to connect the importance of leadership qualities with the relevance of analyzing conflict management in general. We also emphasize that in future the global business will undoubtedly face a talent void, and, consequently, professionals able to think and treat different situations holistically will predominate the labour market. In the article, we also share our own experience of improving our students' leadership qualities. The conflict management grid is analyzed. Based on the recent publications we suggested some crucial steps to be undertaken to achieve success in conflict management.

Key words: business environment, conflict management, cross-cultural teams, leadership qualities, foreign language preparation, future economists, global intercultural environment, managerial grid.
\end{abstract}

\section{Introduction}

Today's ever-changing global business environment and ever-shrinking cultures inevitably pose dangers and challenges not only to businesses to survive but mainly to young people seeking career growth and self-fulfilment. Business success has always been associated with putting yourself into new and challenging circumstances.

McKinsey Global Institute has recently conducted research analyzing future trends in employment and concluded that by 2030 the global manpower will reach 3.5 billion, yet there will be a considerable shortage of talented, highly-skilled and gifted workforce able to think outside the box and treat conflicts holistically (Tsedal Neeley, 2017). It will undoubtedly lead to intensified fierce global competition for talent. Rather than assuming people will work in one location, in their native culture, they will need new skills, attitudes, and behaviours that enable them to work across 
cultures. Hence, our ways of thinking about careers, colleagues, and collaboration will need to become more flexible and adaptable.

Thus, in the highly mobile world to further careers, people have to take up new jobs, move to another country, join new organizations, transfer to new office locations, and meet and build up relationships with new customers, suppliers and industry peers; in other words, we have to constantly dive into new cultures. These changes sooner or later will lead to arising conflicts not only among peers, which is inevitable but notably between cultural perceptions. Cultural awareness along with leadership qualities has already become the current buzzword on the one hand, and the core job prerequisite for a successful business career on the other one. Consequently, businesses are seeking specialists who can address problems from new and innovative angles, handle surprises, learn quickly, and excel in any position. At the same time, young specialists are facing a situation under which they have to adapt their behaviours to new cultural circumstances without losing themselves in the process. In this case, under no means should we violate our sense of ourselves but try to adapt to new cultural peculiarities. It notably relates to excellent leadership qualities, abilities to aspire and influence people.

\section{Literature review}

The question of developing and enhancing leadership qualities in the process of professional as well as post-graduate preparation (coaching sessions) has always been in the scope of such academics, coaches and educators as Abraham Zaleznik, Robert B. Cialdini, David Rooke and William R. Torbert, Alison Doyle, Herminia Ibarra and Otilia Obudaru, Jay A. Conger, Jack Zenger and Joseph Folkman - leadership development consultants). There is much common ground in their views that possession of leadership qualities can bring not only sustainable development to companies but also professional fulfilment and satisfaction.

Business trainers (Martin Pearson, Paul Cummings - practising leadership trainers and mentors) in conjunction with scholars and researchers (Nirocata Takeuchi, Ikujiro Nonaka) state (and the reality proves) that the existing knowledge did not manage to prevent or at least slow down the collapse and recession of global financial system and financial institutions (Lehman Brothers, Washington Mutual) from drastic failures we have witnessed recently (Takeuchi, 2011: 59). We have always thought, preached and taught our students that to be innovative businesses are supposed to capture, store, generate and distribute knowledge because it can trigger their sustainable competitive edge.

Among different classifications of leadership qualities, we can identify so-called «the right stuff» suggested by Daniel Goleman consisting of intellectual abilities, technical skills and emotional intelligence; the persuasion concept of leadership grounded by Jay A. Cogner and the Seven Action Logics leadership concept justified by David Rooke and William R. Torbert (Rooke, 2005). All these approaches to understanding leadership qualities and skills share much in common and conclude that possessing these skills will significantly contribute to prudent problem-solving, sound decisionmaking and fruitful strategy-formulating efforts.

This issue of the importance of acquiring, cultivating and enhancing leadership qualities in the process of professional growth has been profoundly investigated by the Japanese professors Nirocata Takeuchi and Ikujiro Nonaka in their work «The wise leader». We share their approach to its understanding that it closely relates to practical wisdom which is viewed as experimental knowledge that helps people make ethically sound and justified judgments (Nirocata Takeuchi, 2011: 64). 
Over the last years, the issue of cultivating and enhancing leadership skills and qualities has become of current concern in works and studies of Ukrainian scholars and educators such as V. Myhailichenko, O. Romanovskiy, A. Rudska, L. Pashko (leadership as a dominant factor in successful administrative work), S. Shaposhnikova (leadership in institutions of higher education). They mainly focus on investigating the ways and importance of developing leadership skills in future officials, lawmakers and senior managers. Some national scholars, notably O. Swentinskiy, F. Genov, B. Lomov, L. Umanskiy, view leadership as a means of arranging teamwork and achieving organizational goals. So, the national scholars' approach to defining leadership, in general, is confined to business and administrative spheres. Whereas, we can hardly find works describing and analyzing leadership qualities as an integral part of professional business preparation of future economists of international economic affairs. It is customarily assumed that leaders can be groomed when a personality matures and has gained a lot of professional expertise. This point of view is undoubtedly true, but we strongly believe that professional business, economic, management and foreign language preparation at university has a great and untapped potential for developing and boosting these skills and qualities in future economists.

As in our paper, we are pursuing the goal to identify the interdependence between successful conflict management skills and the role of leadership qualities in resolving conflicts in intercultural business environments, we have to take a glimpse at reviewing the national literature dedicated to conflict management. Thus, we have to state that recently, numerous studies on conflict management and ways of resolving conflicts have been conducted using different methods. Such authors as L. Gerasina, M. Panova, T. Dutkevich, M. Prymush, N. Grishyna consider different aspects of managing the conflicts which mainly occurring at the workplace place, during negotiations, psychological aspects of conflicts in managing people, the theoretical background of conflict management. However, there are still some fundamental issues associated with resolving conflicts in the intercultural business environment.

Thus, the goal of this work is to state the interdependence between successful conflict management and leadership qualities and skills on the one hand, and on the other one, to underline the importance to educate leadership qualities and skills in the process of professional preparation of future economists of international economic relations at university.

\section{Research methodology and methods}

Our research is loosely based on the key works of Peter Drucker (1993) dedicated to leadership qualities, works of Daniel Goleman (1995) covering the issues of Emotional intelligence and core principles of conflict management designed by Robert R. Blake and Jane S. Mouton (1979). In analyzing key terms, we use cross-sectional explanatory. By introducing our techniques of cultivating leadership qualities and designing solutions in conflict management, 20 students were offered to take part in a volunteer pool to participate in an in-depth study. They were asked to complete a language-proficiency paper consisting of reading comprehension tasks (answering the questions, choosing options and doing comprehension tests) and writing tasks (designing a roadmap of overcoming cultural barriers).

Before getting down to research, we explained to our students how to undertake thinkaloud protocols and then asked them to think aloud during the tasks. We fell back on using this method of assessing not only our students' level of acquired knowledge but also their cognitive skills of analyzing, critical thinking and concluding abilities.

We took into consideration the methodological issues on researching analytical skills, we attempted in this study to provide a detailed protocol for the collection of the think-aloud data. This 
drew on the work of Ericsson and Simon (1985, 1993), Ericsson (2006), Sasaki (2008), Ferguson et al. (2012), Clinton et al. (2014) and in terms of data analysis on the work of Yang (2003) and Gu (2014) (Li Li and Shirley Larkin, 2017:7).

The paper-based tasks lasted approximately 90 minutes. Following completion of the paper, students were briefly interviewed with questions based on their think-aloud protocol to explore their understanding of key notions and strategy use in completing the paper. Retrospective interviews were conducted in English. Special attention was paid to translation to ensure the accuracy of the data.

\section{Findings and discussions}

We pay special attention to this fact at our educational institution - Kyiv national economic university named after Vadym Hetman. The professional preparation of future economists of international economic affairs at the Department of international economics and management embraces different aspects, such as business knowledge, finance, management, key knowledge of economics and international marketing. Their future professional activities will imply dealing and cooperating with partners from different cultural environments and during this business interaction there might occur misunderstandings and even cross-cultural issues. Professional background and awareness will enable our future economists to find business solutions, but managing conflicts and cross-cultural misunderstandings require not only specialist knowledge but also some qualities and skills. Especially it refers to the ability to influence, inspire, tolerate some drawbacks, have empathy and persuade people. This is the area of expertise of leadership. Unfortunately, these issues are covered in the special disciplines only on the surface.

Consequently, we can see a profound potential in learning a foreign language to combine not only developing and improving language competencies but also through getting acquainted with intercultural business practices our students - future economists will acquire intercultural awareness, cultivate and enhance their leadership qualities and be able to deal with cross-cultural conflicts.

In the process of learning a foreign language (English) our students - future economists of international economic relations profoundly dive into the scope of leadership qualities and selfmanagement skills. When educating students - future economists and managers we clearly and distinctively explain that today's world of business is aimed at achieving outcomes that are beneficial not only for the business itself but mainly for society as a whole. In other words, as Peter Druker once put it, that the modern global society needs knowledge that will «be the centre of the wealth-producing process». Future economists should clearly understand that in their future professional activities they will do better to pursue the common good because this approach will ensure their (professional and business) sustainability. The sine qua non of their professional values is supposed to be the idea of maintaining the common good. To some extend we should cultivate and impose the idea of bringing businesses to live in harmony with society, underlining the importance of having a social purpose in earning profits, pursuing the common good as a pattern of life and having a moral purpose in running a business and practice of distributed phronesis. All our educational attempts should be primarily aimed at teaching integrity in the classroom.

Thus, after reading and analyzing the fundamental works on leadership (Daniel Goleman, Warren Bennis, David Rooke and William R. Torbert), we have understood that the highlighted issues and ideas might be of great interest to those students who study international economics, business and management. That is why clearly understanding these changes in the perception of the challenges and requirements the modern business world has to face and handle, educators and 
scholars have to deliver this understanding to students - future economists and managers in the process of their professional (economic, management and foreign language) preparation. There is a profound gap between the theory educated at universities and practice future specialists face when are hired to bring benefits to the company. When making judgments future economists and managers as potential leaders, executives and even steady performers will have to know that everything is contextual, taking professional actions significantly depends on «doing so in a timely fashion». We are deeply convinced that we, educators, have to persuade our students that in doing business successfully and mutually beneficial for both the society and business itself they will have to pair micromanagement with big-picture aspiration about the future to allow companies to live in harmony with society rather than clash with it.

Thus, there is a current necessity to cultivate prudent, practical leadership skills in students - future economists and managers in the process of their professional preparation. These skills are to be based on so-called practical wisdom which is viewed as tactic knowledge «acquired from experience enabling people to make prudent judgments and take action on the actual situation, guided by values and morals» (Takeuchi, 2011: 65).

In our paper we shall list leadership qualities based on the classification suggested by the Japanese professors Nirocata Takeuchi, Ikujiro Nonaka, and Toyama Royoko. Thus, we share the authors' point of views that the importance of educating and further enhancing leadership qualities and skills stem mainly from individual values, ethics and moral principles and they constitute as follows.

Firstly, all decisions and practical actions of a highly committed leader are subject to his or her moral discernment, in other words, their ability to show prudent judgment in a situation, believing that all their actions imply a moral purpose. The Japanese scholars and practising managers state that a personality's ladder of values is a foundation of leadership qualities. Future economists are supposed to comprehend that their judgments and decisions as managers are to be made based on bringing the common good, not for profits or competitive edge. We suggest four ways of cultivating the ability to make prudent judgments: through experience - listing and analyzing your wins and failures, building your code of principles, prioritizing the tasks and constant personal improvements. Teaching integrity in the classroom as nuts and bolts of the professional education we offer our students to do the suggested assignment: do some kind of personal SWOT analysis, draw up a code of professional ethics stating values and principles, make a list of things or personal characteristics to be improved or enhanced. At least these activities will contribute to critical self-understanding skills. In this case we could also suggest an activity offered by David Rooke and William R. Torbert - a sentence-completion survey tool called the Leadership Development Profile (Rooke, 2005).

Secondly, we should undertake such classroom activities and techniques that are primarily aimed at developing the thinking skills of our future managers which mean grasping the essence of the situation: reasons, consequences and apparent solutions. Cultivating these skills, we should suggest a problematic situation and target students to get to the root of the problem by asking the right questions. We are deeply convinced and share the idea that innovations can be achieved by asking the right things. The management guru Peter Drucker once described the power of provocative questions stating that «the important and difficult job is never to find the right answers, it is to find the right question». To prove this idea in the classroom we should encourage our students to ask the question "Why?», "Why not?», "What if» and as a vivid example to illustrate the cases of innovative ideas and breakthroughs undertaken by CEOs of eBay, PayPal, Skype, Dell Computer owing to asking «what would happen if we did this?». We share and hold the 
viewpoints of Jeffry H. Dyer, Hal B. Gregersen and Clayton M. Christensen that if we start asking ourselves or other people to imagine a completely different alternative it can lead to truly original insights (Dyer, 2009: 64).

As our students, as potential leaders, increasingly have to run their companies in crosscultural business environments, they are persistently urged to deal with conflict management.

Recently, numerous studies on resolving conflicts have been conducted using different methods: surveys, statistical analyses, etc. Today, owing to the findings we have an opportunity to treat conflicts holistically using academic approaches, as we have a separate field of science conflict management. We share the researchers' points of view that conflict management refers to the process of using preferred strategies to handle a conflict with goals of limiting negative impact and enhancing positive influence (Qi Wang, 2015). We support the author's opinion, that conflicts embrace attitudinal, behavioural, or resource-related incompatibility perceived by at least one of the interdependent parties in a given context, mainly business and intercultural environment. When analyzing business cultures and issues surrounding working in the global intercultural environment, our students prepare their projects of introducing a particular business culture, mainly focusing on providing relevant solutions of overcoming cultural misunderstandings and interpersonal conflicts. They even role-play negotiations involving participants from different cultures. In this case they have to illustrate their qualities and skills of resolving conflicts, eliminating their negative impact. We emphasize that conflict resolution is focused on reducing or eliminating conflicts. Our students should clearly understand that conflict management is focused more on strategic implementation for positive outcomes. In our work we introduce the most influential theory around conflict management which is precisely based on the managerial grid developed by two management theorists, Robert R. Blake and Jane, S. Mouton (Blake, Mouton, 1979).

Nowadays all prudent managers and leaders are systematically exploiting this grid which implies five main conflict management strategies: integration (a win-win strategy that is aimed at maximizing mutually beneficial outcomes through open communication); accommodation (a winlose strategy can be achieved through concessions by giving up one's own needs to satisfy the other's); domination (a lose-win strategy by seeking to maximize one's own needs without considering the other's); avoidance (a lose-lose behaviour by withdrawal); and compromise (a giveand-take strategy to meet mutual needs in the middle).

Conflict management is not confined to business and intercultural issues. When we get down to analyzing financial and marketing issues (3-d year and 4-th year of study and learning the English language), our students can get convinced that conflict management can be applied to business management, marketing, communication contexts such as in interpersonal (e.g., family, marital, among groupmates and friendship.), organizational (e.g., macro-level, inter-team, and supervisor-subordinate), intercultural (e.g., host-guest, adaptation, and competence), and public relations (e.g., multinational companies and residents).

During the whole process of learning a foreign language, our students get acquainted with doing business in different cultures. This intercultural context is full of arising conflicts, so conflict management has a natural fit with intercultural dialogue because cultural differences make conflict preordained. At the same time, we should not underestimate the fact that suck conflicts tend to be pseudo-conflict. People working in intercultural business environments perceive these incompatibilities with their values and perceptions of behaviours which result from a lack of familiarity with the other's cultural values and norms rather than discordancy. In our interaction with our students, we constantly insist on open, ethical, and empathetic intercultural dialogue 
which is supposed to be essential for successful conflict management. The key to success in conflict management, in our view, mainly lies undertaking the following steps.

Firstly, a successful leader (either of a team or a company) should undertake research which is to incorporate situational contingencies in implementing and evaluating effective strategies. Secondly, a true leader is supposed to clearly distinguish between different types of conflict such as task-related and social and emotional conflicts, especially in workplace contexts. Thirdly, nor is less important the nature of the conflict. In this case management strategies and impact should be carefully considered from both constructive and destructive perspectives. We agree with Robert R. Blake and Jane S. Mouton, the founders of conflict management, that only in this way people will consider conflict, an inevitable social interaction phenomenon, with less negativity and more problem-solving intention (Robert R. Blake and Jane S. Mouton, 1979).

Some scholar and educators (David Rooke and William R. Torbert) state that as all leaders are facing some transformation stages ranging from opportunists, diplomat, expert, achiever, individualist, strategist to the alchemist, conflict management also refers to conflict transformation (Jonathan Shailor, Professor, University of Wisconsin-Parkside, USA) (Shailor, 2013). The origin of conflict transformation as a concept goes back to the later 20th century and it emerged from the social, political, and cultural struggles we have been facing over the last years.

With this reference to Jonathan Shailor's works, we should state that conflict transformation is a «comprehensive approach that addresses personal, relational, structural, and cultural dimensions of conflict, using the potential for conflict as a catalyst for positive change in all of these areas» (Jonathan Shailor, 2013). The author speaks of the importance, and we agree, of profoundly reconsidering the essence of the conflict itself, especially in the intercultural business context. Instead of seeing conflict as a problem to be managed and resolved, he puts forward the idea that the process of conflict transformation evokes, embraces, and explores differences. It is closely allied to the related concepts of peacemaking and conciliation.

In this approach to understanding the nature of conflict, we explain to our future economists that conflict transformation should be viewed as a gear toward the development of healthier and fruitful communication patterns. We believe that the goals such as personal growth, building up rapport relationships, reducing or eliminating violence, addressing human rights, and increasing democratic participation can be achieved and converted into personal values. The supporters of this concept advocate social change and social justice, across a broad spectrum of society.

While analyzing cases of intercultural conflicts, our students have concluded that intercultural dialogue is a key practice in conflict transformation, as the focus is on communication for better understanding, and the development of relationships, across the boundaries of culture. The more that intercultural dialogue works toward collaborative efforts for progressive social change, the more closely it is allied to conflict transformation. This is the gist our future economists and potential leaders have to get from reading and analyzing various information dedicated to conflict management.

\section{Conclusion}

We should emphasize that the possession of leadership qualities and knowledge will significantly enhance a voyage of personal understanding and development our students - future economists are to be profoundly aimed at. It all relates to the ongoing learning process and negotiating, it requires commitment and practice, especially in today's business contingencies and ambiguity. The right understanding of the importance of cultivating leadership skills initially based 
on prudence and practical wisdom can smoothly transform today's knowledge-creating companies into tomorrow's wisdom-practising ones. Especially this process is becoming of paramount importance in resolving conflicts arising in the intercultural business context. We hold the opinion that a new type of business leader is supposed to possess and exercise watertight thinking skills by acquiring new knowledge because of continuous improvement, efficiency and perfection, but acting on the principles of action logic and practical wisdom. People living and working together in intercultural communities and companies crave purpose. We can all add more value when we can anticipate better things to come. Leadership is a lifelong journey. Learning to be a leader is virtually the same process as becoming an integrated and healthy person.

Thus, we should conclude that in the process of professional and language preparation of future economists of international economic relations we have to make a significant shift towards educating and improving our students' leadership qualities and skills as a dominant factor in resolving and managing cross-cultural misunderstanding and conflicts in intercultural business environments. Students have to clearly understand the importance of respecting business cultures, ways of doing business and interacting with other cultures; they have to educate and enhance such qualities as empathy, emotional intelligence, self-control and be ready to tolerate other cultures.

\section{References}

Blake, R. R., \& Mouton, J. S. (1979). Principles of behavior for sound management. Training and Development Journal, 33(10), 26-28.

Galtung, J. (2004). Transcend and transform: An introduction to conflict work. London: Pluto Press.

Shailor, J. (2013). Toward a theory of managing organizational conflict. International Journal of Conflict Management, 13, 206-235

Li, L. \& Larkin, Sh. (2017). The role of metacognition in the success of reading and writing tasks across cultures. ELT Research Papers. 10 Spring Gardens London SW1A 2BN, UK. British Council Publishing.

Lederach, J. P. (2003). The little book of conflict transformation. Intercourse, PA: Good Books.

Rooke, D., \& Torbert, W. R. (2005). Seven Transformations of leadership. HBR. https://hbr.org/2005/04/seven-transformations-of-leadership

Smith, D. G., Johnson, W. B., \& Stromberg, L. (2021). How men can be more inclusive leaders. https://hbr.org/2021/05/how-men-can-be-more-inclusive-leaders

Satell, G., Windschitl, C. (2021). High-performing teams start with a culture of shared values. https://hbr.org/2021/05/high-performing-teams-start-with-a-culture-of-shared-values

Tsedal, N. (2017). How to Successfully Work Across Countries, Languages, and Cultures. HBR. https://hbr.org/2017/08/how-to-successfully-work-across-countries-languages-and-cultures

Takeuchi, N., \& Nonaka, I. (2011). The wise leader. HBR. https://hbr.org/2011/06/wise-leadership

Wang, Q. (2015). Conflict management. Key Concepts in Intercultural Dialogue. centerforinterculturaldialogue.files.wordpress.com/2016/12/kc53-conflict-management$\underline{\mathrm{v} 2 . \mathrm{pdf}}$ 
Александрова Наталія

\section{удосконалення лідерських якостей для управління конфліктами в умовах міжкультурної взаємодії \\ (в контексті професійної та іншомовної підготовки спеціалістів з міжнародних економічних питань)}

В статті обґрунтовується актуальність формування та розвитку лідерських якостей та вмінь для розв'язання конфліктних ситуацій в бізнесі. Проаналізувавши сучасні тенденції розвитку бізнесу як в країні, так і за ї̈ межами, а також, звертаючи увагу на підходи до управління та розв'язання конфліктів в міжкультурному діловому середовищі, встановлено відповідні вимоги до майбутніх економістів міжнародного профілю. На основі аналізу класичних та сучасних джерел з управління конфліктами та лідерства з'ясовано, що сучасний бізнес розвивається на теренах сталого розвитку і в умовах міжкультурної взаємодії, що висуває нові вимоги до професійної та іншомовної підготовки студентів - майбутніх економістів міжнародного профілю в економічному університеті. Автор підкреслює важливість і значущість набуття міжкультурної компетентності, знань з основ управління конфліктами та формування лідерських якостей, що стає можливим при вивченні іноземної мови. Актуальність нашого дослідження полягає в тому, що ми поєднали значущість формування управлінських якостей в розв'язанні конфліктів в умовах міжкультурної взаємодії. Зміна акцентів в професійній та іншомовній підготовці майбутніх економістів в бік формування лідерських якостей та розширення знань з міжкультурної взаємодії уможливлює процес формування цілісної особистості майбутніх фахівців і знизить ризики створення міжкультурних конфліктів.

Ключові слова: ділове середовище, управління конфліктами, лідерські якості, міжкультурні команди, іншомовна підготовка, майбутні економісти, міжкультурне середовище, управлінська матриця.

\section{Інформація про автора:}

Александрова Наталія

- Кандидат педагогічних наук, доцент

- Україна

- ДВНЗ «Київський національний економічний університет імені Вадима Гетьмана», доцент кафедри іноземних мов та міжкультурної комунікації

- ORCID Id: 0000-0002-7902-2434

— E-mail: natik76aleksandrova@gmail.com

Aleksandrova Nataliya

- PhD in Pedagogy, Associate Professor

- Ukraine

- Kyiv National Economic University named after Vadym Hetman

- Associate professor at Foreign Languages and Cross-Cultural Communication Department 